\title{
Leksikografska praksa pri Čehih in Slovakih
}

\author{
Andrej Perdih
}

Cobiss: 1.19

Česká a slovenská výkladová lexikografia na začiatku 21. storočia: súbor príspevkov v rámci medzinárodného projektu Princípy a metódy tvorby výkladového slovníka, ur. Jindra Světlá - Alexandra Jarošová - Albena Rangelova, Brno: Tribun EU, 2011, 220 str.

Zbornik Česká a slovenská výkladová lexikografia na začiatku 21. storočia ${ }^{1}$ prinaša odgovore in odprta vprašanja, povezana z izdelavo leksikografskih del, ki trenutno nastajajo na Češkem in Slovaškem. Prispevki predstavljajo spoznanja in izkušnje, pridobljene ob nastajanju leksikalne baze češkega jezika Pralex in slovarja slovaškega jezika Slovník súčasného slovenského jazyka, ki je do zdaj izšel v dveh zvezkih (A-G in H-L). Za zbornikom Lexikografie v kontextu informační společnosti ${ }^{2}$ je to drugi zbornik z leksikografsko tematiko, ki je nastal v sodelovanju Inštituta za češki jezik Češke akademije znanosti in Jezikoslovnega inštituta L'udovíta Štúra Slovaške akademije znanosti.

Za slovenski prostor je zbornik zanimiv zlasti zato, ker pri nas trenutno nastajata splošni razlagalni slovar in leksikalna zbirka slovenskega jezika, v obravnavanem zborniku pa lahko najdemo osvetlitev nekaterih leksikografskih vprašanj. Njegova vsebina namreč izhaja iz praktičnih in konceptualnih leksikografskih dilem in njihovih rešitev ali predlogov za rešitve v češki leksikalni bazi (prvih 16 prispevkov) oziroma v slovaškem slovarju (3 prispevki).

Pri izdelavi češke leksikalne baze Pralex je kot vsebinsko izhodišče in delovna opora uporabljen zlasti slovar Slovník spisovného jazyka českého, v manjši meri tudi drugi češki razlagalni slovarji in slovarji tujk, gradivno pa korpus orig_syn (prej imenovan SYN), ob čemer Pralex v češki prostor prinaša seveda tudi nekatere metodološke novosti. Ta dvojnost, torej pregled dosedanjih rešitev v češki leksikografiji in nove rešitve v leksikalni bazi, je še posebej zanimiva, saj so v prispevkih prikazane in utemeljene razlike, nastale bodisi zaradi razvoja leksikografije bodisi zaradi drugačne namembnosti leksikalne baze v primerjavi s slovarjem.

Slovar sodobnega slovaškega jezika je obsežno leksikografsko delo in bo ob izidu vseh zvezkov postal v slovaškem prostoru drugi veliki splošni razlagalni

1 Dostopen je na spletnem naslovu http://www.lexiko.ujc.cas.cz/texts/sbornik_cely_imprimatur.pdf.

2 Lexikografie v kontextu informační společnosti: sborník přispěvků z pracovního setkání, Praha, 4.-6. 6. 2007, ur. A. Rangelova - J. Světlá - A. Jarošová, Praha: Ústav pro jazyk český AV ČR, 2008. 
slovar. V tem zborniku so mu namenjeni le trije prispevki, zainteresiranega bralca lahko zato za več razmišljanj o slovaškem slovarju ponovno napotim na zbornik, naveden $\mathrm{v}$ opombi.

Prvi del zbornika prikazuje delo pri leksikalni bazi češkega jezika Pralex s poudarkom na obravnavi samostalnikov. Jindra Světlá v prispevku Struktura a zpracování hesel v lexikální databázi Pralex (9-18) predstavlja cilje in načrtovano pot do ciljev v okviru leksikalne baze češkega jezika ter predstavlja najprej tehnične naloge, torej izdelavo namenske programske opreme, nato pa še vsebinske naloge od konceptualnih vprašanj in osnovnih napotkov za delo do konkretnejših vprašanj o makro- in mikrostrukturi, kjer prikazuje tudi dejansko mikrostrukturo leksikalne baze. Leksikalna baza bo med drugim služila kot izhodišče za pripravo tako splošnega enojezičnega razlagalnega slovarja kot drugih slovarskih del. Ista avtorica v naslednjem prispevku (Budování hesláře lexikální databáze Pralex, 19-27) predstavlja merila za izdelavo geslovnika leksikalne baze, katerega izhodišče je Frekvenční slovník češtiny, glavne dopolnitve prihajajo iz slovarja Slovník spisovného jazyka českého, deloma tudi iz korpusa SYN, v prihodnje pa bodo upoštevani tudi drugi viri. Dve avtorici, Jindra Světlá in Barbora Procházková (K základnímu zpracování substantiv v lexikální databázi Pralex, 29-38), opisujeta osnovna načela obravnave samostalnikov in strukturo gesla $\mathrm{v}$ leksikalni bazi.

Marta Koutová (Exemplifikace substantiv v lexikální databázi Pralex (zpracování př́ikladové části hesla), 39-50) predstavlja glavno nalogo pri obravnavi gesel $\mathrm{v}$ leksikalni bazi, tj. ponazarjalno gradivo, ki ga črpajo iz korpusa orig_syn, in v okviru tega prikazuje način izbora in razvrščanja kolokacij in stavčnih zgledov. Edith Čonosová (Zpracování zdrobnělin v lexikální databázi Pralex, 51-57) predstavlja obravnavo manjšalnic. Zanimiv je prikaz drugostopenjskih manjšalnic glede na (ne)izkazanost prvostopenjske manjšalnice ali podstave, pa tudi dvojne razlage (besedotvorne in pomenske) glede na tip manjšalnice. Martina Habrová (Zpracování antonym v lexikální databázi Pralex, 59-67) prikazuje obravnavo protipomenk pri samostalnikih.

Helena Pernicová (Zpracování názvů osob a jmen přechýlených v lexikální databázi Pralex, 69-76) se osredotoča na poimenovanja oseb in iz njih tvorjena poimenovanja oseb nasprotnega spola. Pri tem izpostavlja zlasti vprašanja razlag in homonimije. O regionalnih, pokrajinskih in narečnih leksikalnih enotah (brez »obecne« češčine) piše Hana Goláňová (Ke zpracování regionálních lexikálních jednotek v lexikální databázi Pralex, 77-84). Dotika se ne le vprašanja merila ozemeljske razširjenosti pri teh leksikalnih enotah, ampak tudi vprašanja meje med knjižnostjo in neknjižnostjo. Ker je število pojavitev teh leksikalnih enot v korpusu orig_syn majhna, si za njihovo potrditev in vrednotenje pomagajo z dodatnimi viri. Avtorica piše, da poleg korpusa in slovarjev upoštevajo tudi češki jezikovni atlas in novejše narečne zbirke. Eva Podruhová (Základní charakteristika kompozit v lexikální databázi Pralex, 85-93) prikazuje obravnavo delov zloženk v leksikalni bazi, pri čemer se upošteva izvor, variantnost, homonimija, antonimija in sinonimija. Pri komponentah, ki so sinonimne zaradi razmerja tuje - domače, prikazuje njihovo distribucijo v zloženkah. Avtorica prikazuje tudi tipološko delitev glede na pomenska polja.

Za obravnavo zaimkov je poskrbel Vojtěch Veselý (Ke zpracování zájmen v lexikální databázi Pralex, 95-103). Obravnava vprašanja homonimije zaimkov s 
samostalniki, prislovi, členki in medmeti, variantnosti, poleg tega pa tudi slovničnih značilnosti zaimkov, ki so pomembne za obravnavo. Ne izogiba se obravnavi zaimkov v frazemih. Jana Letafková (Zpracování vlastních jmen v lexikální databázi Pralex, 105-114) pojasnjuje merila za uvrstitev lastnih imen v leksikalno bazo. V prispevku se osredotoča zlasti na osebna imena in njihove variacije, pri tem pa se dotika tudi vprašanja homonimije in polisemije. Del lastnih imen, namreč hipokoristična lastna imena, obravnava Radek Volejník (Zpracování hypokoristik v lexikální databázi Pralex, 115-124), ki prikazuje njihovo tipologijo, obravnava stil razlag, čustveno zaznamovanost in razmerje med homonimijo in večpomenskostjo, opisano pa je tudi izbiranje in razvrščanje ustreznih zgledov v leksikalni bazi.

Eva Kolovecká (Zpracování přirovnání v lexikální databázi Pralex, 125-136) prikazuje redakcijo primerjav v smislu frazemov v leksikalni bazi Pralex in obravnava določanje slovarske oblike primerjav, obravnavo fakultativnih delov, variant in transformacij. Dotika se tudi razlagalnega sloga. Zdeňka Opavská v svojem prispevku (Zpracování víceslovných lexikálních jednotek v lexikální databázi Pralex (se zaměřením na zpracování nefrazeologických víceslovných lexémů), 137-152) piše o obravnavi večbesednih leksikalnih enot $\mathrm{v}$ leksikalni bazi in primerjavo $\mathrm{z}$ načinom obravnave $\mathrm{v}$ čeških slovarjih, o merilih za uvrstitev večbesednih enot kot samostojna gesla ali kot zglede znotraj gesla katere od enot besedne zveze, dotakne se tudi razmejitve frazemov od ostalih stalnih večbesednih enot. Prispevek Albene Rangelove (Typologie abreviačních útvarů v lexikální databázi Pralex, 153-164) prinaša pregled obravnave krajšav v več čeških slovarjih in tipologijo krajšav, ki izhaja iz leksikoloških raziskav, predstavlja pa tudi način prikaza krajšav v Pralexu glede na njihovo tipološko uvrstitev. Iz prispevka Zdeňke Tiche (Jednopísmenné zkratky a značky ve slovnících a v lexikální databázi Pralex, 165-173) izvemo, katere enočrkovne krajšave so za leksikalno bazo češčine relevantne in kako poteka njihovo iskanje v korpusu.

Drugi del zbornika je sestavljen iz slovaških izkušenj pri izdelavi Slovarja sodobnega slovaškega jezika. Klára Buzássyová (K aspektom tvorenia antonymných lexém s prefixom ne- (nominácia, lexikalizácia, pragmatické komponenty, 175191) v svojem prispevku prikazuje sredstva za izražanje protipomenskosti kot formalno-semantične informacije, ki poleg sinonimov dopolnjujejo razlago leksikalnih enot $\mathrm{z}$ nikalnično predpono ne- $\mathrm{v}$ pripravljajočem se tretjem zvezku Slovarja sodobnega slovaškega jezika (M-O). Opozarja, da je pri leksikografskem delu s potencialnimi protipomenkami, ki jih leksikograf zazna intuitivno, nujno preveriti njihovo sintagmatično povezljivost, saj se izkaže, da številnih potencialnih protipomenk na podlagi tega merila ne moremo obravnavati kot protipomenke. Jana Hašanová in Nicol Janočková (Sloveso ako lexikografická výzva, 193-205) prikazujeta ugotovitve in izkušnje, pridobljene pri zaključevanju redakcije glagolov v drugem zvezku slovarja, zlasti gre za vprašanja velelnika pri procesnih glagolih, deležniškega trpnika povratnih in nepovratnih glagolov, variantnosti slovničnih oblik pri nekaterih glagolih, vprašanje neosebnih glagolov in neosebnih oblik osebnih glagolov ter vprašanje povratnih in nepovratnih glagolov sploh. Alexandra Jarošová (Ustálené prirovnania: problémy ich chápania a lexikografického zachytenia, 207218) obravnava primerjave zlasti v smislu njihovega razumevanja in problemov pri 
- slovarski obravnavi. Tako v prispevku pojasnjuje, kateri teoretični pristopi, kon[. $=$ struktivne kritike prvega zvezka slovarja in drugi vsebinski pomisleki so redaktorje N vodili h konceptualni spremembi obravnave primerjav v drugem zvezku slovarja.

V zborniku je številsko razmerje med češkimi in slovaškimi prispevki močno nagnjeno v korist prvih, pa tudi po vsebini prispevki obravnavajo različne teme - če so češki avtorji dali poudarek samostalnikom in zaimkom, pri Slovakih ni skupne rdeče niti. Na žalost zato ne moremo na enem mestu primerjati različnih pristopov in izkušenj pri istih vprašanjih $\mathrm{v}$ dveh časovno in jezikovno podobnih, a ciljno precej različnih leksikografskih delih. To je po eni strani razumljivo, saj so morala biti nekatera vprašanja, ki jih v zborniku obravnavajo češki avtorji, za slovaški slovar razrešena že pred izidom prvega zvezka leta 2006, zato je aktualnost vprašanj za posamezen projekt različna, po drugi strani pa to razmerje $\mathrm{v}$ zborniku deluje nekoliko neenotno. Na splošno menim, da je obravnavani zbornik s svojo praktično usmeritvijo koristen za osvetlitev leksikografskih vprašanj, saj so dileme prikazane v luči iskanja praktičnih rešitev, obenem pa je pri obravnavanih temah prikazano razmerje med teoretično in konceptualno izčiščenimi redakcijskimi pravili in tistim delom leksikografovih odločitev, ki tudi po vzpostavitvi pravil ostanejo v domeni t. i. jezikovne kompetence posameznega redaktorja ali redakcijske skupine. Teme, obravnavane v zborniku, so v tem času aktualne tudi za slovenske bralce. 